\title{
Intra-abdominal abscess formation from the ingestion of a fish bone
}

\author{
Gurdeep S Mannu, ${ }^{1}$ Krystian Pawelec ${ }^{2}$
}

- Additional material is published online only. To view please visit the journal online (http://dx.doi.org/10.1136/bcr2014-207717)

${ }^{1}$ Department of General Surgery, Oxford University Hospitals NHS Trust, Oxford, Oxford, UK

${ }^{2}$ Department of General Surgery, Stoke Mandeville Hospital, Stoke Mandeville, Buckinghamshire, UK

\section{Correspondence to} Dr Gurdeep S Mannu, gurdeepmannu@gmail.com

Accepted 28 October 2014
CrossMark

To cite: Mannu GS, Pawelec K. BMJ Case Rep Published online: [please include Day Month Year] doi:10.1136/bcr-2014207717

\section{DESCRIPTION}

A 63-year-old man presented with left upper quadrant abdominal pain, constipation and fever for the past few weeks. His medical history was significant for a previous endovascular repair of a right common iliac artery aneurysm. On examination he had a temperature of $38^{\circ} \mathrm{C}$ and a $13 \times 8 \mathrm{~cm}$ palpable mass in the left upper quadrant of his abdomen. The rest of the examination was unremarkable.

His blood tests revealed $\mathrm{C}$ reactive protein of $245 \mathrm{mg} / \mathrm{L}$ and white cell count of $14.8 \times 10^{9} / \mathrm{L}$. Ultrasound investigation of the palpable mass revealed a $8.4 \times 4.9 \times 4.4 \mathrm{~cm}$ mass with internal echoes and a hyperechoic focus, thought to be a foreign body. CT scan showed a linear object of calcific density, such as a fish bone, embedded just within the abdominal cavity deep to the peritoneum and surrounded by an abscess measuring $4.7 \times 2.7 \mathrm{~cm}$ across (figure 1A, B). This lesion had been incidentally noticed on previous imaging predating the endovascular repair 2 years prior when it was located within a much smaller inflammatory collection and asymptomatic. It appeared that the suspected fish bone had perforated through the intestine and over the 2 years formed an enlarging abscess cavity now located relatively superficially.

An exploratory laparotomy was performed and the abscess cavity evacuated and fish bone retrieved. The small bowel proximal to the vicinity of the abscess appeared dilated due to a compression effect from the abscess and this explained the patient's constipation. He made an uneventful recovery and was discharged home 4 days later. Although bowel perforation from ingested fish bones has been rarely described in the literature, ${ }^{1-3}$ to the best of our knowledge it has not been previously described presenting after such a long period of time.

\section{Learning points}

- Foreign body ingestion should always be considered as part of the differential diagnosis of any acute abdominal pain.

- When examining any lump, basic principles should be adhered to such as establishing its relation to surrounding structure, texture, size, shape and fluctuance.

- A detailed history, careful clinical examination and an appropriate choice of investigation tests are essential in planning operative management of an ingested foreign body.
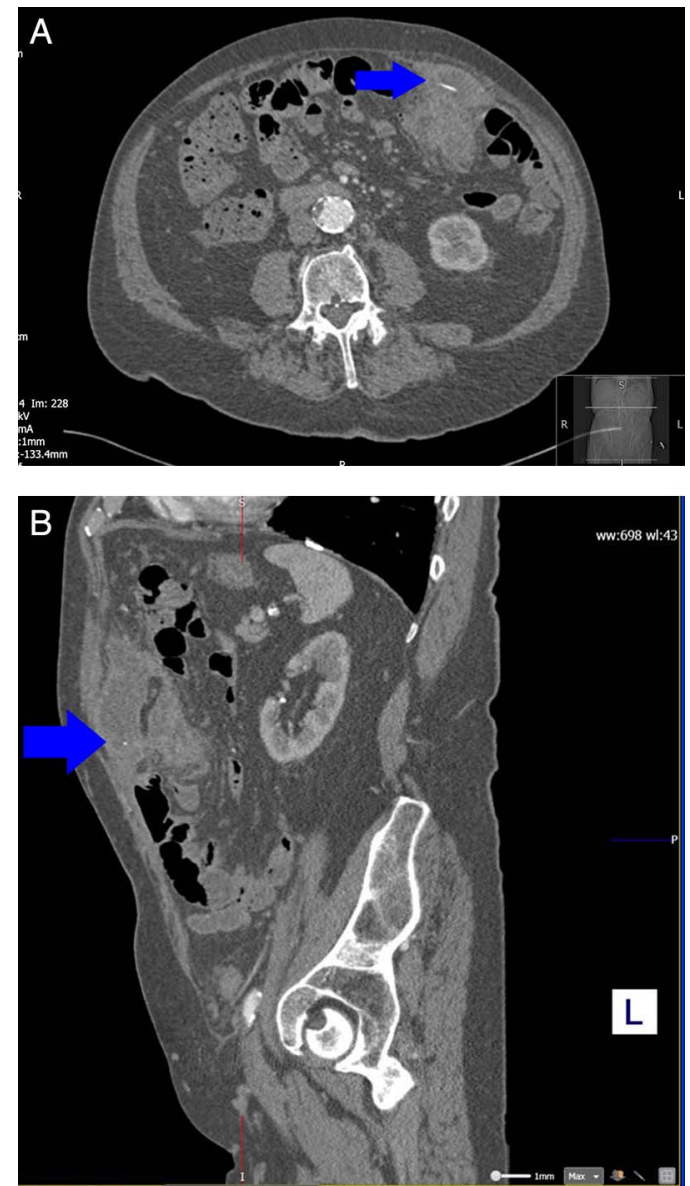

Figure 1 (A) Horizontal view of the CT scan demonstrating an intra-abdominal mass with fish bone. (B) Coronal view of the CT scan demonstrating intra-abdominal mass with fish bone present.

\section{Competing interests None.}

Patient consent Obtained.

Provenance and peer review Not commissioned; externally pee reviewed.

\section{REFERENCES}

1 Bathla G, Teo LL, Dhanda S. Pictorial essay: complications of a swallowed fish bone. Indian J Radiol Imaging 2011;21:63-8.

2 Costa Almeida CE, Rainho R, Gouveia A. Codfish may cause acute abdomen. Int J Surg Case Rep 2013:4:969-71.

3 Wu CX, Wu BQ, Duan YF, et al. Rare case of omentum-wrapped abscess caused by a fish bone penetrating the terminal ileum. World J Gastroenterol 2014:20:11456-9. 
Copyright 2014 BMJ Publishing Group. All rights reserved. For permission to reuse any of this content visit http://group.bmj.com/group/rights-licensing/permissions.

BMJ Case Report Fellows may re-use this article for personal use and teaching without any further permission.

Become a Fellow of BMJ Case Reports today and you can:

- Submit as many cases as you like

- Enjoy fast sympathetic peer review and rapid publication of accepted articles

- Access all the published articles

- Re-use any of the published material for personal use and teaching without further permission

For information on Institutional Fellowships contact consortiasales@bmjgroup.com

Visit casereports.bmj.com for more articles like this and to become a Fellow 